\title{
PARASITIC THYROID NODULE IN A PATIENT WITH HASHIMOTO'S CHRONIC THYROIDITIS
}

\author{
Vitorino Modesto dos Santos, Marcus Aurelho de Lima, Eurípedes Oliveira \\ Marinho, Marco Aurélio de Oliveira Marinho, Lister Arruda Modesto dos Santos \\ and Cristiane Mendes Raphael
}

RHCFAP/3005

\begin{abstract}
SANTOS V M dos et al. - Parasitic thyroid nodule in a patient with hashimoto's chronic thyroiditis. Rev. Hosp. Clín. Fac. Med. S. Paulo 55(2):65-68, 2000.

SUMMARY: A case of parasitic thyroid nodule is presented. The patient was a non symptomatic 53-year-old white woman, on irregular course of L-thyroxine to treat hypothyroidism due to Hashimoto's thyroiditis. Without a history of thyroid trauma or surgery, she presented a 1.6 x $0.7 \times 0.5 \mathrm{~cm}$ right pre-laryngeal lymph node-like mass which, on ultrasonography, appeared distinct from the gland. TSH, thyroid peroxidase antibody and thyroglobulin antibody serum levels were elevated and T4-free level was normal. Thyroid and total body ${ }^{99 \mathrm{~m}} \mathrm{Tc}$ isonitrile scintiscan showed a topic thyroid without radionuclide uptake in the nodule. Fineneedle aspiration of the nodule showed epithelial cells with nuclear atypia and oncocytic changes plus intense lymphoid infiltration and germinative center formation, simulating lymph node metastasis of papillary thyroid carcinoma. Conventional biopsy revealed a parasitic thyroid nodule with Hashimoto's chronic thyroiditis. Parasitic thyroid nodule must always be remembered so that unnecessary surgical assessment and undesirable sequels may be avoided.
\end{abstract}

DESCRIPTORS: Thyroid. Parasitic nodule. Sequestered nodule. Accessory nodule. Hashimoto's chronic thyroiditis.

Ectopic thyroid tissue is usually described as being situated in the medial or lateral cervical region, between the base of the tongue and the gland's normal site, due to thyroid migration disorders during embryogenesis ${ }^{1}$. Besides that condition, portions of thyroid tissue may be mechanically separated from the gland and develop as accessory nodules.

These nodules, also termed parasitic or sequestered, do not show any lymph node architectural vestiges and may or may not be connected to the thyroid by a pedicle ${ }^{1-5}$. This benign condition, considered rare, may constitute a serious diagnostic dilemma when one suspects lymph node metastasis from an occult thyroid carcinoma ${ }^{1,2,4}$, ${ }^{6}$. Parasitic nodules have been de- scribed in association with Graves disease and colloid goiter ${ }^{1,3}$.

Recently, we examined a case of parasitic thyroid nodule in a female with Hashimoto's chronic thyroiditis. The needle aspiration biopsy sample resembled papillary thyroid carcinoma lymph node metastasis.

\section{CLINICAL CASE}

A 53-year-old non symptomatic woman, body mass index $25.0 \mathrm{~kg} / \mathrm{m}^{2}$, with no history of trauma or thyroid sur-

From the Department of Medical Clinic, Triangulo Mineiro University, School of Medicine and the Cancer Combact Association of Brazil. gery, and in a long term irregular use of L-thyroxin to treat hypothyroidism due to Hashimoto's chronic thyroiditis, presented a slow growing anterior cervical nodule. Physical examination revealed normal thyroid and a painless, smooth, fibro elastic non adherent $1.5 \mathrm{~cm}$ palpable nodule just beside the laryngeal prominence. The nodule did not seem to have connection with the gland. Routine laboratory tests were all normal. TSH $(6.46 \mathrm{mUI} / \mathrm{ml})$, anti thyroid peroxidase $(832.0 \mathrm{UI} / \mathrm{ml})$ and anti thyroglobulin $(43.7 \mathrm{UI} / \mathrm{ml})$ serum levels were elevated and T4-free (1.16ng/dl) level was normal, suggestive of subclinical hypothyroidism. Thyroid ultrasonography revealed decreased volume $\left(3.69 \mathrm{~cm}^{3}\right)$, right lobe $1.7 \mathrm{~cm}^{3}$, left lobe $1.68 \mathrm{~cm} 3$, isthmus $0.3 \mathrm{~cm}^{3}$, with a diffuse hetero- 
geneous aspect, suggestive of chronic thyroiditis and a $0.8 \times 0.7 \mathrm{~cm}$ nodule without connection with the upper portion of the gland but in the same fascial plane (Fig. 1). ${ }^{99 \mathrm{~m}} \mathrm{Tc}$ isonitrile (MIBI) scintiscan of the thyroid and total body showed a normal topic thyroid with no radionuclide uptake in the separated nodule (Fig. 2).

Fine-needle aspiration biopsies of the thyroid and of the nodule were performed. Nodule aspiration revealed groups of epithelial cells with irregular nuclei, nuclear grooving and/or intranuclear cytoplasmic inclusions, surrounded by abundant mature lymphocytes. Lymph node metastasis of papillary thyroid carcinoma was suspected (Fig. 3). Thyroid aspiration revealed intense lymphocyte infiltrates, occasional plasmocytes, and epithelial cells with oncocytic changes, compatible with Hashimoto's chronic thyroiditis. Patient was submitted to a nodule resection which appeared as a chestnut colored, smooth and brilliant $1.6 \times 0.7$ x $0.5 \mathrm{~cm}$ mass. Microscopically, thyroid parenchyma represented by small and medium sized follicles surrounded by cells with irregular and voluminous nuclei presenting some nuclear grooving and cytoplasmic inclusions was observed. Cytoplasma were either scanty or abundant and granular, with an oncocytic appearance. Thyroid follicles were permeated and surrounded by an intense inflammatory lymphoid infiltrate forming germinative centers (Fig. 4). The absence of marginal sinuses in all the silver staining sections dismissed the possibility of thyroid tissue in the lymph node. Diagnosis: parasitic thyroid nodule with Hashimoto's chronic thyroiditis.

\section{DISCUSSION}

Besides embryogenic disorders, trauma or surgery on the gland, the presence of sequestered thyroid tissue

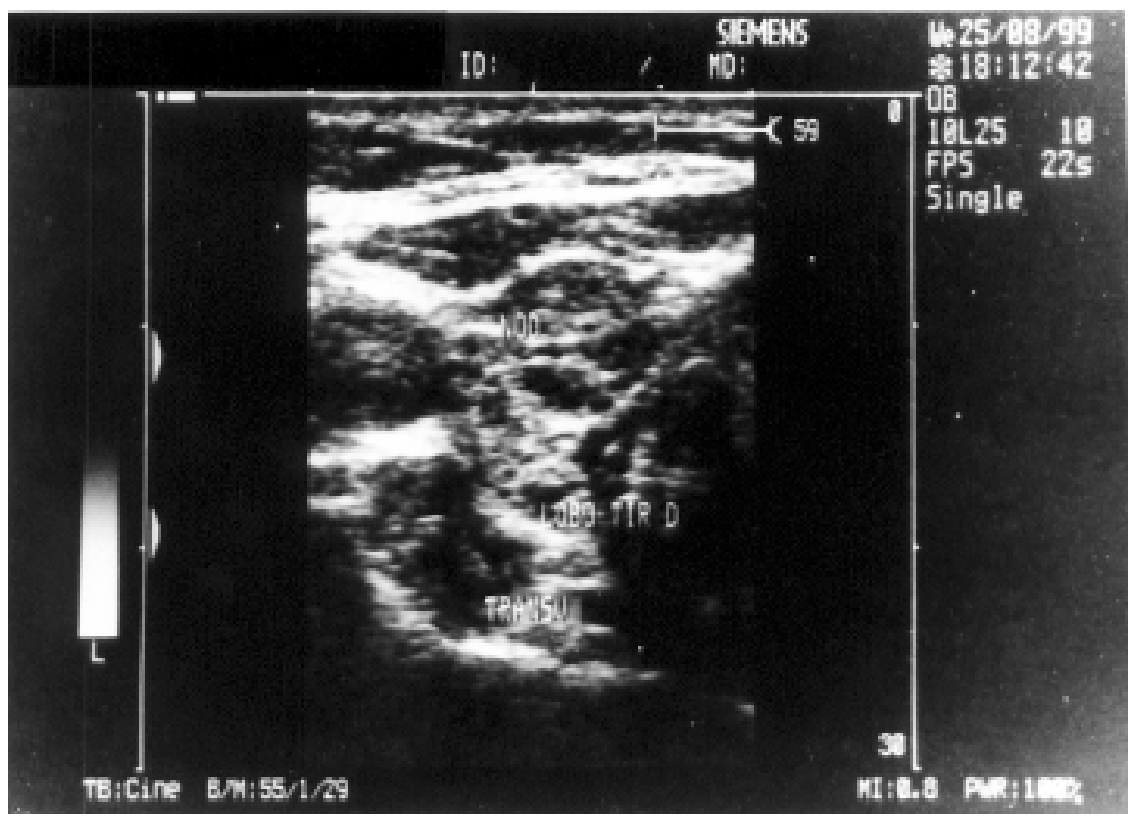

Figure 1 - Thyroid ultrasonography revealed a diffuse heterogeneous aspect, suggestive of chronic thyroiditis, and a nodule, $0.8 \times 0.7 \mathrm{~cm}$, in the same fascial plane of the gland and without contact with the upper limit of the right lobe.

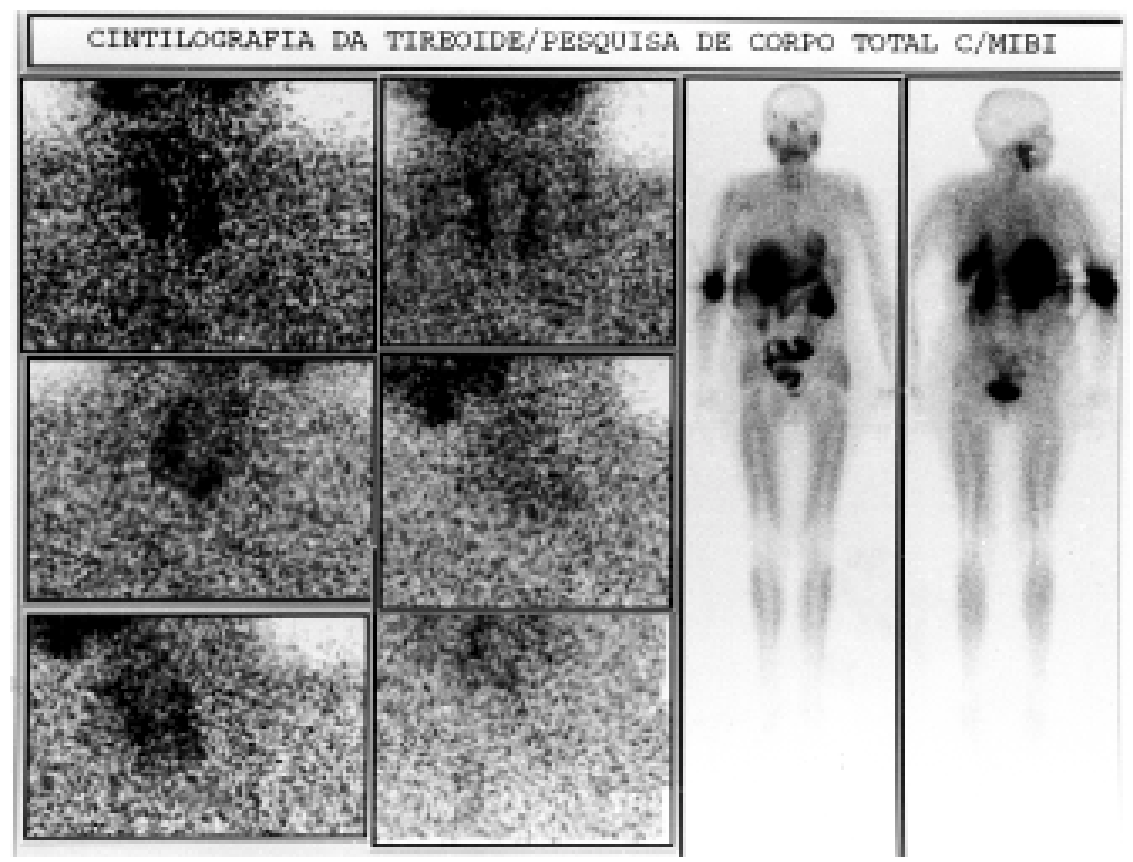

Figure 2 - ${ }^{99 \mathrm{~m}} \mathrm{Tc}$ MIBI scintiscan of thyroid and of total body showed a normal topic thyroid with no radionuclide concentration in the parasitic nodule.

has been related to the mechanical action of neck muscles in cases of nodular colloid goiter. Projecting portions of the goiter, extending through the fascia, may be severed by muscular pres- sure and separated from the thyroid. In such case, the appearance is that of nodular goiter, without any evidence of malignancy both in the gland and the nodule ${ }^{3,5}$. 


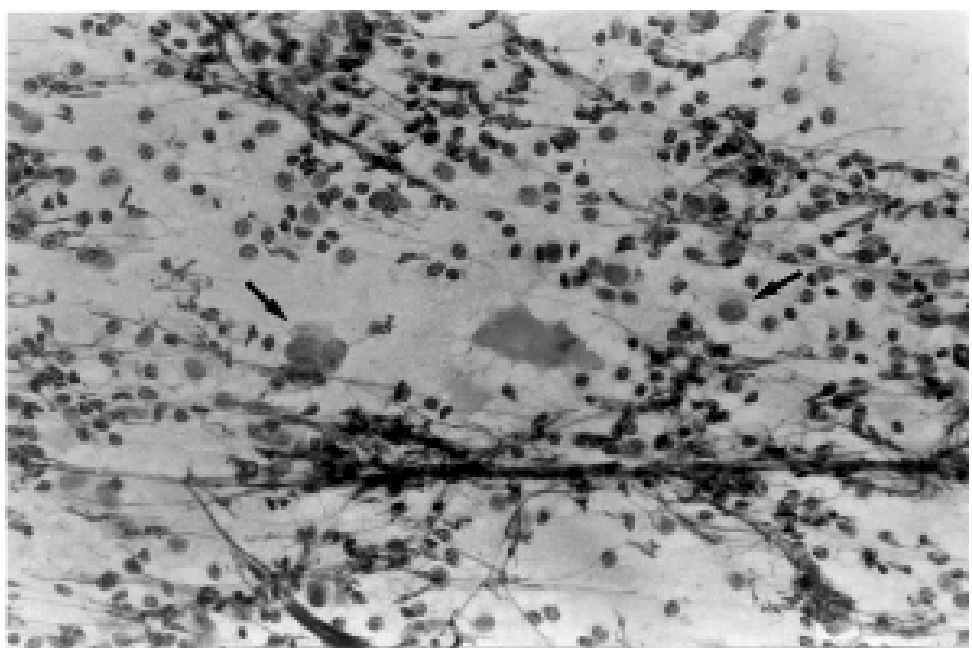

Figure 3 - Photomicrography of nodule aspiration showing groups of epithelial cells with irregular nuclei (arrows), surrounded by abundant mature lymphocytes, simulating lymph node metastasis of papillary thyroid carcinoma (HE 400X).

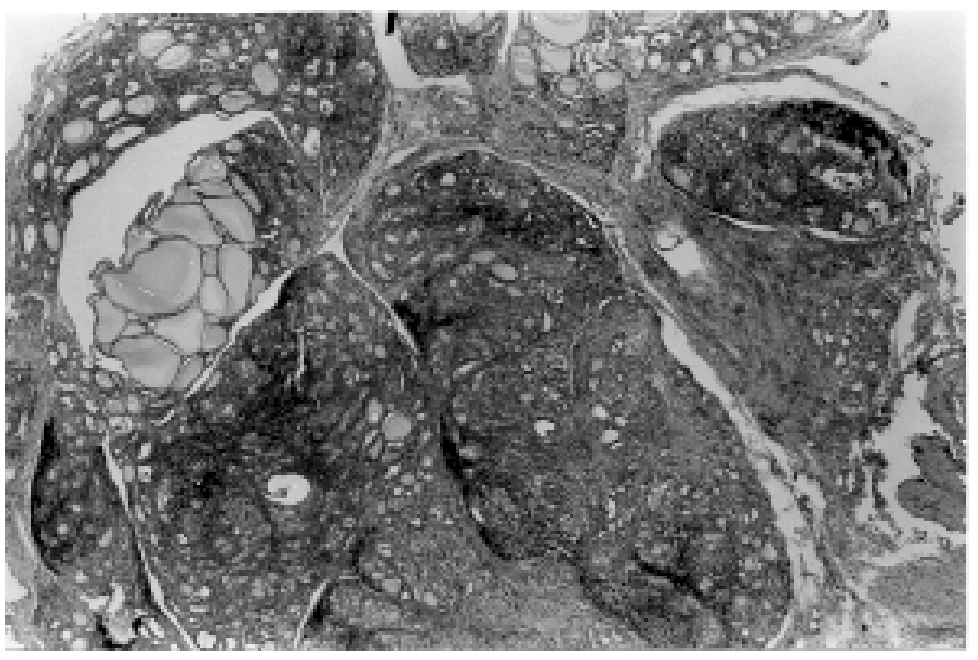

Figure 4a - Fotomicrography of the thyroid nodule showing Hashimoto's chronic thyroiditis (HE 40X)

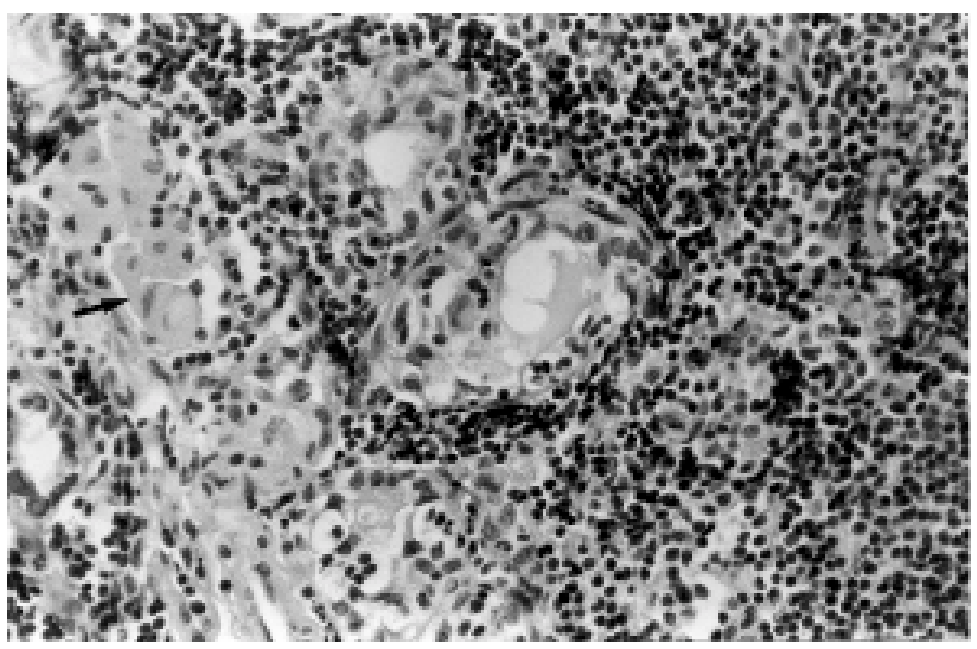

Figure 4b - In detail, Hashimoto's chronic thyroiditis characterized by thyroid follicles with nuclear atypia and oncocytic changes (arrow), in addition to intense lymphocytic inflammatory infiltrate (HE 400X).
The diagnosis of thyroid parasitic nodule requires that the tissue be placed in the same fascial plane as the thyroid, be unassociated with the lymph node and exhibit a similar histological aspect as the gland. The anatomical relationship between the nodule and the thyroid may be lost or missed, as occurs in cases of parasitic uterine leyomioma ${ }^{4}$.

Our patient had Hashimoto's chronic thyroiditis and, on physical examination, she presented a topic thyroid and an accessory thyroid nodule in the anterior cervical region, separated from the gland. In such cases, besides lymph node metastasis, one must consider the possibility of benign conditions such as implants of thyroid tissue after trauma or surgery and thyroid inclusion in cervical lymph nodes?

In the present case, the diagnosis of a parasitic nodule was confirmed by the absence of any lymph node architectural association; fact which dismissed the possibility of thyroid tissue inclusion in the lymph node. The lack of trauma or surgery in the gland discounted the possibility of mechanical implants. Although the presence of nuclear atypia and cytoplasmic changes associated with lymphoid follicles were suggestive of papillary lymph node carcinoma metastasis, this diagnosis was also discounted by the absence of marginal sinuses in all the silver staining sections examined ${ }^{5}$.

In Hashimoto's thyroiditis, abundant lymphocytic inflammatory infiltrate and germinative centers formation, may simulate lymph node metastasis of papillary thyroid carcinoma, especially the follicular variant ${ }^{1,6}$. If there was metastasis from papillary thyroid carcinoma in this patient, total thyroidectomy and group VI lymph node dissection should be performed. Therefore, parasitic thyroid nodule must always be remembered so that unnecessary surgical assessment and undesirable sequels may be avoided. 
SANTOS V M dos e col. - Nódulo tireoidiano parasítico em paciente com tireoidite crônica de Hashimoto. Rev. Hosp. Clín. Fac. Med. S. Paulo 55(2):65-68, 2000.

Relata-se caso de nódulo tireoidiano parasítico em mulher branca, 53 anos, assintomática, sem antecedentes de trauma ou cirurgia, usando irregularmente L-tiroxina para hipotireoidismo decorrente de tireoidite de Hashimoto. O nódulo, situado na região pré-laríngea direita, media 1,6 $\mathrm{x}$ $0,7 \times 0,5 \mathrm{~cm}$, estando separado da tireóide, conforme ultra-sonografia. Os níveis de TSH, anticorpos antitireóide peroxidase e antitiroglobulina estavam elevados, com T4-livre normal. Cintilografia da tireóide e corpo total com ${ }^{99 \mathrm{~m}} \mathrm{Tc}$ isonitrila mostrou glândula tópica, sem captação no nódulo. Punção biópsia aspirativa com agulha fina demonstrou atipias nucleares e alterações oncocíticas nas células epiteliais e acentuado infiltrado linfocitário formando centros germinativos, simulando metástase linfática de carcinoma papilífero. Biópsia convencional revelou nódulo parasítico com tireoidite crônica de Hashimoto. Tratando-se de metástase de carcinoma papilífero de tireóide, tireoidectomia total e dissecção de linfonodos do grupo VI estariam indicadas. Para evitar procedimentos cirúrgicos desnecessários e seqüelas indesejáveis, deve-se sempre considerar a possibilidade de nódulo tireoidiano parasítico.

DESCRITORES: Tireóide. Nódulo parasítico. Nódulo seqüestrado. Nódulo acessório. Tireoidite crônica de Hashimoto.

\section{REFERENCES}

1. SHIMIZU M, HIROKAWA M \& MANABE T - Parasitic nodule of the thyroid in a patient with Graves' disease. Virchows Arch 1999; 434:241-244.

2. ASSI A, SIRONI M, DI BELLA C et al. - Parasitic nodule of the right carotid triangle. Arch Otolaryngol Head Neck Surg 1996; 122:1409-1411.

3. LIU RS, YEN TC, YEH SH et al. - Scintigraphic demonstration of sequestered nodular goiter. A lateral aberrant thyroid rest. Clin Nucl Med 1992; 17:402-403.

4. ROSAI J - Thiroid gland. In: ROSAI J - Ackerman's Surgical Pathology. $8^{\text {th }}$ ed. St Louis, Mosby, 1996. p. 493-567.
5. SISSON JC, SCHMIDT RW \& BEIERWALTES WH - Sequestered nodular goiter. N Engl J Med 1964; 270:927-932.

6. HOMAN MR, GHARIB H \& GOELLNER JR - Metastatic papillary cancer of the neck. A diagnostic dilemma. Head Neck 1992; 14:113-118.

7. MEYER JS \& STEINBERG LS - Microscopically benign thyroid follicles in cervical lymph nodes. Serial section study of lymph node inclusions and entire thyroid gland in 5 cases. Cancer 1969; 24:302-311.

Received for publication on the: 16.03 .00 